DEVELOPING INNOVATIVE SOLUTIONS THROUGH COLLECTIVE ENTREPRENUERSHIP: AN INTEGRATED FRAMEWORK KOLEKTIF GIRIŞIMCILIK YOLUYLA YENILIKÇİ ÇÖZÜMLER GELIŞTIRME. KAPSAYICI BIR ÇERÇEVE Özge CAN"

\begin{tabular}{ll}
\hline $\begin{array}{l}\text { Geliş Tarihi: } 17.07 .2020 \\
\text { (Received) }\end{array}$ & $\begin{array}{l}\text { Kabul Tarihi: 03.06.2021 } \\
\text { (Accepted) }\end{array}$ \\
\hline
\end{tabular}

ABSTRACT: This study provides an extensive discussion on how collective entrepreneurship strategies by multiple organizational actors both within and across sectors can yield innovative solutions to several problems. Although the emphasis in the entrepreneurship literature has been largely on initiatives by single actors, combinations and complementarities of resources through partnerships can significantly help produce novel approaches to the ongoing socioeconomic, environmental, political and institutional challenges. How such collective entrepreneurial systems are developed, what the main collaboration dynamics among actors are, how these systems can be managed, and when and where such collective action can produce innovative results are only a few of the curious questions to answer. An important aspect is to understand how seemingly unrelated actors across diverse sectors collaborate. To this end, this study provides an inclusive theoretical framework on how collective entrepreneurial action stimulates innovative outcomes for organizations by evaluating the level, type and characteristics of entrepreneurial collectives. Even though there has been increasing interest in collective entrepreneurship, this is the first attempt where an integrated model is provided to understand this essential phenomenon.

Key Words: collective entrepreneurship, institutional entrepreneurship, crosssectoral collaborations, market creation, innovation

ÖZ: Bu çalışma, aynı ya da farklı sektörlerden gelen örgütsel aktörlerin ortak girişimcilik stratejileri sayesinde nasıl birçok soruna yenilikçi çözümler getirebilecekleri üzerine kapsamlı bir tartışma sunmaktadır. Girişimcilik yazını büyük ölçüde tekil aktörlerin girişimlerine vurgu yapsa da, ortaklıklar yoluyla kaynakların bir araya getirilmesi ve tamamlanması mevcut sosyoekonomik, çevresel, politik ve kurumsal sorunlara yeni yaklaşımlar üretilmesine önemli katkı sağlar. Bu tür kolektif girişimcilik sistemlerinin nasıl geliştirildiği, aktörler arasındaki temel işbirliği dinamiklerinin neler olduğu, bu sistemlerin nasıl yönetileceği ve bu kolektif eylemlerin nasıl ve ne zaman yenilikçi sonuçlar verebileceği yanıtlanması gereken sorulardan sadece birkaçıdır. Farklı sektörlerden gelen, görünüşte ilgisiz aktörlerin nasıl işbirliği yaptıklarını anlamak özellikle önemlidir. Bu çalışma, kolektif girişimciliğin düzeylerini, türlerini ve özelliklerini değerlendirerek örgütler için yenilikçi sonuçların nasıl ortaya çıktığı konusunda kuramsal bir çerçeve

* Dr. Öğr. Üyesi, Yaşar Üniversitesi, ozge.can @ yasar.edu.tr, ORCID: 0000-0001-83626719. 
önermektedir. Yazında kolektif girişimciliğe yönelik artan bir ilgi olmasına rağmen, bu önemli olguyu anlamak için ilk kez kapsamlı bir model sunulmaktadır.

Anahtar Kelimeler: kolektif girişimcilik, kurumsal girişimcilik, sektörler arası işbirlikleri, pazar yaratma, yenilik.

\section{GENIŞLETILMIŞ ÖZET}

Bireysel girişimciler, girişimcilik yazınının odak noktasında bulunsa da, kolektif dinamiklere ve girişimciliğin birden çok aktör arasında eşgüdümlü eylemlerin bir işlevi olmasına yönelik artan bir ilgi söz konusudur (Schoonhoven ve Romanelli, 2001). Bunun nedeni, girişimciliği var eden dinamiklerin farklı düzey ve boyutlarda birbirine bağlı olması, tek bir kişinin veya belli bir örgütün sınırlarının çok ötesine geçmesidir. Örgütler, pazar yaratma, pazarı genişletme, olan pazarı koruma (Rao vd. 2000; Corbett ve Montgomery, 2017; Lee vd. 2017) ya da çevresel belirsizliğe ve çatı̧san kurumsal mantıklara çözüm bulma (Rao vd. 2000; Dufays, 2013; Yan ve Yan, 2017) gibi ortak hedef ve çıkarlara sahiptir. Bu koşullar altında, yeteneklerini ve yaratıcılıklarını bir arada ve uzun vadeli biçimde kullanabilecekleri kolektif girişimcilik kapasiteleri devreye girer (RibeiroSoriano ve Urbano, 2009).

Kolektif girişimciliği anlama çabaları artmasına rağmen, mevcut tartışmalar hayli kopuk ve zayıftır. Bu tür işbirliklerinin gerektirdiği ortak hedefler ve mekanizmalar ile bu unsurların kolektif girişimciliğin belirli biçimleri ve düzeyleri ile nasıl örtüştüğü yeterince anlaşılamamış ve tartışılmamıştır. Oysa ki, oluştuğu bağlam ve içerisinde yer alan aktörler açısından kolektif girişimcilik çabaları önemli farklar gösterecektir (Burress ve Cook, 2009).

Yukarıdakiler çerçevesinde bu araştırmanın amacı, kolektif bir bakış açısı geliştirmenin mevcut girişimcilik bilgisine nasıl katkıda bulunabileceğini sistematik bir şekilde tartışmak ve açıklamaktır. Yazındaki kavramsallaştırmaların derinlemesine incelenmesi sonucunda kapsamlı bir kolektif girişimcilik modeli geliştirilmiştir. Bu model, iki ana bölümden oluşmaktadır: a) girişimcilik düzeyi; b) kolektif girişimcilik çabalarının temel unsurları. Davidsson ve Wiklund'un (2001) ve Burress ve Cook'un (2009) çalışmalarından esinlenerek, kolektif girişimciliğin ortaya çıkabileceği ve etkilerinin deneyimlenebileceği dört ayrı düzey belirlenmiştir.

En düşük düzey, girişimciliğin müşteriler, tedarikçiler, dağıtım kanalları veya diğer işbirlikçiler arasında doğduğu, resmi/gayri resmi stratejik ittifaklar ve değer zinciri gibi ağlar ile tezahür eden örgütler arası ilişkilerden oluşur. Bu düzeydeki girişimciliğin kapsamı genellikle ekonomik kazançlar elde etmek, rekabet avantajını artırmak veya ă üyeleri için yeni bir ürün/hizmet geliştirmek için iş firsatlarını keşfetmek ve kullanmak için güçlerin birleştirilmesiyle sınırlıdır. Endüstri veya küme düzeyinde, kolektifteki üye sayısı artar (bazen bir endüstrinin tüm katılımcılarını içerir) ve ilişkiler daha az hiyerarşik hale gelir. Vurgu, yeni endüstri standartları belirlemek, yeni bir pazar kategorisi yaratmak veya yeni bir organizasyon biçimini meşrulaştırmak gibi daha geniş beklentilere kayar. Kaynaklar genellikle kolektif kimlikler inşa etmek için seferber edilir. 
Bölgesel veya topluluk düzeyinde ise girişimcilik bölgesel ekonomik büyüme ve kalkınma veya yerel yenilik kapasitesinin arttırılması için firsatları keşfetmenin ve kullanmanın bir yolu olarak görülür. Buna göre, belirli bir coğrafyadaki çeşitli yerel gruplar (örneğin işletmeler, topluluk temsilcileri, yerel yönetimler) işbirliğine girer. Son olarak, ulusal/toplumsal düzey, toplumsal bir konuyu ve olası çözümleri bilinir hale getirmek veya yeni bir kamu politikası inşa etmek gibi geniş düzeyde sosyal ve siyasi değişiklikleri teşvik etme amacı ile gerçekleştirilen toplu girişimcilik çabalarını temsil eder. Bu amaçla, daha fazla sayıda ve farklı aktör (örneğin devlet kurumları, üniversiteler, sosyal hareketler, iş dünyası) karşılıklı çıkarlar doğrultusunda etkileşime girer.

Önerilen çerçevenin ikinci kısmı, herhangi bir kolektif girişimcilik süreci için geçerli olan temel unsurları ve kararları içeren altı boyuttan oluşur: 1) kurumsal alan/aktör tipi (tek sektör/homojen ya da farklı sektörler/heterojen), 2) aktörlerin katılım tarzı (merkezi aktörler, çevresel aktörler), 3) değer yaratma şekli (benzer kaynaklar ya da farkll, birbirini tamamlayan kaynaklar), 4) ilişkilenme düzeyi (zayıf ağlar; güçlü ağlar), 5) işbirliğinin vadesi (kısa-orta vade, uzun vade), 6) temel hedef (işlemsel ya da bütünleştiricidönüştürücü).

İlk unsur olan kurumsal alan, kolektifin katılımcılarına göre kompozisyonunu yansıtır. Ortaklar aynı sektörden geliyorsa daha homojen bir kolektif ortaya çıkar. Buna karşılık, farklı sektörlerden aktörler güçlerini birleştirirse, girişimci toplam daha heterojen hale gelir. İkinci unsur katılım tarzıdır. Girişimci kolektifler içindeki aktörler, ya değerli kaynakları (çekirdek aktörler olarak) bir araya getirerek piyasa firsatları yaratmaya aktif olarak katılırlar ya da bu faaliyetlere çevre aktörleri olarak destek verirler (Corbett ve Montgomery, 2017 ). Üçüncü unsur, sağlanan kaynaklarla ilgilidir. Girişimciler, her şeyden önce kaynakların yeniden birleştirilmesi yoluyla değer yaratır. Ancak bu yeniden birleştirilecek kaynakların türüne ve doğasına bağlıdır. Kaynaklar "benzer ve genel" veya "tamamlayıcı ve benzersiz" olabilir (Austin ve Seitanidi, 2012; Montgomery vd. 2012).

Girişimci kolektifteki aktörlerin çıkarlarının yakından bağlantılı olup olmadığı başka bir temel boyuttur. Bu çıkarlar sıkı bir şekilde bağlantılı olduğunda, diğer bir deyişle, katılımcılar arasındaki karşılıklı bağımlılık yüksek ise, bu onların fikirleri, inançları ve eylemlerinin daha uyumlu olduğu ve daha güçlü bir şekilde değer yarattıkları anlamına gelir. Beşinci unsur, zamanla ilişkilidir. Kolektif girişimcilik, işbirliği için öngörülen zaman aralığına bağlı olarak da kısa-orta vadeli bir işbirliği veya uzun vadeli bir girişim olabilir. Son olarak, girişimcilik kapasitesini birden çok aktör arasında bir araya getirmedeki ana hedef, kolektif çabanın yapısını ve yönünü şekillendirir. Bazı durumlarda amaç köklü bir değişim veya dönüşüm başlatmak iken, bazılarında bir dizi işlem ve bu işlemlerden elde edilen ekonomik kazançla sınırlıdır.

Tanımlanan bu altı unsurun sıklıkla farklı birleşmelerle kendini gösterdiği, yani bazı özelliklerin birbirleriyle diğerlerinden daha iyi uyum sağladığı söylenebilir. Örneğin, girişimci kolektifin bir dönüşüm hedefi varsa, genellikle kısa vadeli değil uzun vadeli bir ufuk söz konusudur. Tanımlanan özellikler ile girişimci eylemin gerçekleştiği düzey arasında da anlamlı bir eşleşme vardır. 
$\mathrm{Bu}$ çalışma, mevcut girişimcilik yazınına farklı şekillerde katkıda bulunmaktadır. Öncelikle, kahraman bireyler veya tekil örgütler fikrinin ötesinde daha gerçekçi bir girişimcilik perspektifi geliştirilmiş ve sunulmuştur (Weik, 2011). Bu ise, örgütsel alanlarda girişimci eylemlerin makro düzeyde dönüştürücü gücünü inceleme ihtiyacına yönelik yazındaki güncel çağrılara yanıt vermektedir (Townsend vd. 2018). İkincisi, bu çalışmayla yeni kurumsal mantıkları, yapıları ve örgütsel alanları yaratan işletmeler, devlet, sivil toplum kuruluşları ve diğer aktörler arasındaki işbirliği eylemlerinin temel boyutları belirlenmiş, hangi girişimcilik koşullarının yenilikçi sonuçlara yol açabileceği netleştirilmiştir (Etzkowitz ve Klofsten, 2005). Üçüncüsü, bu çalışma tekil aktörlerin belli bir alandaki konumlarına ve ilişkilerine bağlı olarak ekonomik, sosyal, teknolojik ve kurumsal bağlamdaki firsatları nasıl daha iyi tanıyabileceklerini göstermektedir (Shepherd vd. 2019). Son olarak, bu araştırma bireysel ve kolektif girişimcilik süreçlerinin birbirlerinden nasıl farklılaştığını ve varsa kesişme noktalarını değerlendirme firsatı sunmaktadir.

\section{INTRODUCTION}

Even though individual entrepreneur is the predominant attraction point in entrepreneurship literature, there has been an increasing interest in collective dynamics and how entrepreneurship is a function of coordinated actions across multiple actors (Schoonhoven and Romanelli, 2001). This is because issues are typically interconnected, going beyond the single person or the boundaries of a specific organization, more so in today's intertwined business world than it was ever before. Organizations usually share common goals and interests with respect to creating, expanding, shaping or protecting markets (Rao et al. 2000; Corbett and Montgomery, 2017; Lee, Struben and Bingham, 2017) or finding solutions to environmental uncertainty and conflicting institutional logics (Dufays, 2013; Yan and Yan, 2017). In these circumstances, collective entrepreneurial capability comes into the picture by drawing upon the talents and creativity in a synergistic way and using them in the long run (Ribeiro-Soriano and Urbano, 2009). So far, collective or institutional entrepreneurship frameworks have been adopted in several different subject areas such as knowledge building around research institutions (Leyden and Link, 2013), community development (Meyer, 2020), environmental protection and recycling (Lounsbury, 1998, Wigger and Shepherd, 2020), social movements and advocacy (Malo, Buendia-Martinez and Vezina, 2012), market formation (Lee et al. 2017), emergence of new industries (Emin and Guibert, 2017) and regional innovation (Cooke, 2009).

Despite the growing attention given to understanding collaborative entrepreneurial efforts, existing discussions are rather disconnected and several gaps exist regarding the specific goals and mechanisms such collaborations entail and how these elements correspond with the particular form and level of collective entrepreneurship. Above and beyond, significant variation is observed with respect 
to at what level collective entrepreneurship is formed and what type of actors are involved (Burress and Cook, 2009). It can refer to a combination of individuals within the organization (Yan and Yan, 2017), or a set of diverse actors can associate at the inter-organizational, industrial, regional or societal level (Anderton and Setzer, 2018; Davidsson and Wiklund, 2001). Involvement of closer (e.g. partners in the same supply-chain) or more distant actors (businesses, government agencies and NGOs) might also let to very different forms of collective entrepreneurship. Finally, the collective understanding might evolve around diverse issues and challenges (e.g. Mintrom, 1997; Montgomery et al. 2012; Sarpong et al. 2017). All these attributes will lead to different entrepreneurial effects and outcomes for the collective and its members.

To this end, the purpose of this research is to provide an extensive review of the relevant research and to describe the ways how a collective perspective can contribute to existing knowledge of entrepreneurship. A collective entrepreneurship framework is developed based on an in-depth investigation on how such collaborations have been conceptualized in the literature. To provide a more refined analysis, it will be done by focusing on the entrepreneurial dynamics across organizations instead of the interaction of individual entrepreneurs within an organization. By doing so, this study will contribute to the existing research by developing an inclusive perspective for understanding collective entrepreneurial types, actions and outcomes. Second, it will support managers regarding how and when to engage in entrepreneurial options in a collective manner to endure and prosper in competition, particularly to be able to generate innovative answers to shared problems.

\section{OVERVIEW OF COLLECTIVE ENTREPRENEURSHIP RESEARCH}

This section summarizes the existing collective entrepreneurship research where the core theoretical ideas and discussions are identified regarding the key attributes of collective entrepreneurship, the rationale behind entrepreneurial collective action, activities and common mechanisms of such action.

\subsection{Key Attributes of Collective Entrepreneurship}

Collective entrepreneurship refers to a process in which diverse actors such as businesses, public agencies, universities, NGOs combine their distinct competences in a synergistic way to discover, develop and implement innovative and mutually beneficial solutions to common, large-scale and complex problems (Doh et al. 2019). The collective nature is related to the fact that several actions such as completing inputs, filing resource gaps, forming new businesses, reshaping institutions, creating new markets and introducing change are achieved by a cluster of public and private actors who share similar interests, and work together (Burress and Cook, 2009; Silva and Rodrigues, 2005; Micelotta, Lounsbury and Greenwood, 2017). Hence, it may also be regarded as a business model where a 
community of organizations are linked as a network with the aim of identifying innovation opportunities and capturing value from long-term innovative solutions (Miles et al. 2006). An important emphasis in the literature is that such innovation is best conceived when organizational actors from different institutional spheres (private, public, non-profit) combine their efforts in a complementary way (e.g. Morgan, 2016; Sarpong et al. 2017) so that diverse talents and visions can be mobilized and attention can be directed to produce creative outcomes.

The notion of collective entrepreneurship has been discussed in various studies and the common attributes of it were identified as involving in an intensive collaborative work, combining multiple resources in distinct ways and seeking large-scale innovative and adaptive responses by a group instead of a single actor (Montgomery et al. 2012; Doh et al. 2019). Determined by shifting opportunity structures in the environment, collective entrepreneurship can only emerge through constructing social webs and shared cognitive frames (Lounsbury, 1998). Joint decision-making, management and learning leads to the discovery, development and scaling of possible innovative solutions.

While some researchers argue that entrepreneurship is inherently or frequently collective, a more fitting view is to see collective entrepreneurship as a distinct case as it entails unique effects on the structure and process of entrepreneurship and brings a number of distinct challenges that are not present for the single entrepreneurial actor (Burress and Cook, 2009). That is, the collective synergistic capability goes beyond the widespread yet limited understanding of entrepreneurship where single lonesome heroes find and seize opportunities from the environment and use them for their own interest (Lounsbury, 1998; Yan and Yan, 2017). Moreover, this type of entrepreneurial capacity is socially complex and path-dependent which makes it quite peculiar and difficult to emulate.

In collective entrepreneurship, assets are jointly owned and the decisions on them are jointly made, thus individual judgment do not apply (Bijman and Doorneweert, 2010). There is a set of economic activities where different resources such as skills, experience, know-how and capital are exchanged and mutually utilized and these activities are organized and decisions are made within a governance structure (Silva and Rodriguez, 2005). Moreover, such collaborations are built based on strong social networks and relationships. If these networks are not readily available, they have to be created (Sarpong et al. 2017). This conception also coincides with the idea that relational processes embedded in specific historical and socio-cultural contexts are the prerequisite for the development of collective entrepreneurship (Lounsbury, 1998). Hence, such innovative systems cannot be easily built. This is also supported by Olson's (1965) well-known depiction of collective action where he argues that unless strong incentives are provided, it is difficult for single actors to come together and put collective efforts 
for attaining common goals beyond individual interests (Wijen and Ansari, 2001). According to this, collective entrepreneurship depends on a set of necessary conditions, structural elements and processes.

As an integration of the above discussions, Ribeiro-Soriano and Urbano (2009) identify strategy, structure and management philosophy as the three fundamental aspects of collective entrepreneurship. Strategy reflects the shared direction and motivation of entrepreneurial group. Once organizational actors with diverse capabilities or coming from different industries/sectors join forces, they can pursue large-scale and sustainable innovative strategies (Miles et al. 2006). Structure refers to the flexible organizing, communication and coordinated relationships of the group members whereas management philosophy concerns with the shared cognitive frames, meanings, values and the trust among them (Lounsbury, 1998; Miles et al. 2006; Sarpong et al. 2017). Altogether, these dimensions enable diverse entrepreneurial actors to utilize ideas, resources and capabilities in a collaborative manner at cognitive, affective and behavioral levels.

\subsection{Why Collective Entrepreneurship Develops}

The key rationale underlying collective entrepreneurship is that the resources, capacity and efforts of a single entrepreneur are inadequate for handling complicated issues and overcoming large-scale challenges, which are deeply rooted in the economic and sociocultural context. Long term changes are often associated with uncertainty which requires adopting long innovation horizons, leveraging complementary resources and experimenting and evolving together (Doh et al. 2019). Hence, one can argue that collective entrepreneurship is most needed and effective when the environment is uncertain, dynamic, competitive and heterogeneous (Anglin et al., 2018; Yan and Yan, 2017).

In uncertain environments, the scarcity or lack of knowledge requires single actors to depend on any information and support provided by others to reduce the ambiguity. Likewise, dynamic environments often entail rapid market, regulatory and technological changes that necessitates engaging in entrepreneurial activities in a collaborative manner so that innovative solutions can be developed much faster (Anglin et al. 2018). Another situation stimulating collective entrepreneurship is environmental hostility. Intense competition in an industry reduces available opportunities and resources drastically and combining different ideas and talents becomes more critical in such intimidating and risky settings (Yan and Yan, 2017). Similarly, when elements in an environment (e.g. rivals, institutions, customers, social forces) are very diverse, nonstandard strategies and practices should be employed and capabilities by a single actor will be insufficient (Anderton and Setzer, 218). Thus, it motivates adding up complementary resources and alternative approaches across multiple actors. In summary, when solutions take long time, several components interact in a complex way, there is a weak and scattered 
resource base and everything is rapidly changing, there is a greater need to promote interaction among organizations from different spheres.

Below, Table 1 presents possible effects and positive outcomes of collective entrepreneurship as described in a selected set of entrepreneurship studies. The effects referred in the literature can be classified into a number of categories: First major category of outcomes is about gaining economic value and rents for a certain group (e.g. strategic partners, network of firms) supporting the commercialization process and increasing competitive advantage which cannot be achieved through single entrepreneurship (e.g. Bijman and Doorneweert, 2010; Burress and Cook, 2009; Yan and Yan, 2017; Pathak et al. 2019). Second category constitutes benefits in discovering, developing, exploiting collective opportunities in markets and fields, and in turn, helping new business establishments (e.g. Cantù, 2018). On the next level, it represents the emergence of new business forms, industries and markets (e.g. Rao et al. 2000; Corbett and Montgomery, 2017).

Other commonly cited benefits of collective entrepreneurship, as a third category, entail how it increases knowledge absorption capacity, directs research attention and supports innovation ideas and processes at a large extent (e.g. Miles et al., 2006; Auerswald and Branscomb, 2003; Sarpong et al. 2017). Positive outcomes in the fourth category typically reflect a broader level of analysis including the ones for an economic region, industrial district or communities such as increasing local economic growth and development, promoting regional cooperation and competitiveness; and creating positive externalities (e.g. Burress and Cook, 2009; Morgan, 2016; Ndour and Alexandre-Leclair, 2015). A final category indicates outcomes in an even broader scale; challenging the status quo, stimulating large scale political transformation, helping achieve adoption of new policies and regulations, supporting and legitimizing new institutions in a particular field or in the society (e.g. Lounsbury, 1998; Zito, 2001; Meijerink and Huitema, 2010).

To put it briefly, there might be a variety of motivations and outcomes of collective entrepreneurship. It should also be noted that some of the categories identified in Table 1 may come into play together as different motives complement one another or as a positive effect triggers others. For instance, emergence of a new market or market category often demands the fall of old institutions and regulations and legitimization of new ones. While collective entrepreneurship efforts support regional development, it typically happens through improving the innovative capacity and infrastructure of that region. Likewise, regional economic growth is usually linked with the national-level sociopolitical transformations and the emergence of large-scale policies. Thus, one should always keep in mind that collaborative entrepreneurial actions produce certain mechanisms leading to a multiple set of results in an interactive way. 
Table 1. Outcomes of Collective Entrepreneurship

\begin{tabular}{|c|c|c|}
\hline Outcome Category & Study & Specific Theme \\
\hline \multirow[t]{4}{*}{$\begin{array}{l}\text { 1. Economic } \\
\text { performance }\end{array}$} & Burress and Cook (2009) & $\begin{array}{l}\text { Economic rents inaccessible to the sole } \\
\text { entrepreneurs }\end{array}$ \\
\hline & Yan and Yan (2017) & $\begin{array}{l}\text { Enhanced performance and sustainable } \\
\text { competitive advantage }\end{array}$ \\
\hline & $\begin{array}{l}\text { Bijman and Doorneweert } \\
(2010)\end{array}$ & $\begin{array}{l}\text { Helping organizations benefit from } \\
\text { economies of scale and scope }\end{array}$ \\
\hline & Pathak (2019) & $\begin{array}{l}\text { Economic value creation for } \\
\text { communities or particular groups }\end{array}$ \\
\hline \multirow[t]{4}{*}{$\begin{array}{l}\text { 2. Emergence of new } \\
\text { business forms, } \\
\text { markets \& industries }\end{array}$} & Cantù (2018) & $\begin{array}{l}\text { Discovering, developing, exploiting } \\
\text { collective opportunities for new } \\
\text { business formation }\end{array}$ \\
\hline & $\begin{array}{l}\text { Corbett and Montgomery } \\
(2017)\end{array}$ & $\begin{array}{l}\text { Formation and legitimization of new } \\
\text { market categories }\end{array}$ \\
\hline & Lounsbury (1998) & $\begin{array}{l}\text { Emergence of new markets and } \\
\text { institutions; increased status and } \\
\text { reputation; construction of new } \\
\text { collective identities }\end{array}$ \\
\hline & Rao et al. (2000) & $\begin{array}{l}\text { Framing new practices, mobilizing } \\
\text { resources and capturing legitimacy for } \\
\text { new forms }\end{array}$ \\
\hline \multirow[t]{4}{*}{$\begin{array}{l}\text { 3. Innovative ideas, } \\
\text { processes \& outputs }\end{array}$} & Yan and Yan (2017) & $\begin{array}{l}\text { Increased knowledge absorption } \\
\text { capacity and implementation of } \\
\text { innovative ideas }\end{array}$ \\
\hline & Sarpong et al. (2017) & $\begin{array}{l}\text { Directing research attention to } \\
\text { productive outcomes for potential users; } \\
\text { exploration and exploitation of } \\
\text { innovation opportunities; supporting the } \\
\text { triple helix }\end{array}$ \\
\hline & Miles et al. (2006) & $\begin{array}{l}\text { Augmenting individual innovative } \\
\text { efforts; enhancing innovation-driven } \\
\text { wealth creation }\end{array}$ \\
\hline & $\begin{array}{l}\text { Auerswald and Branscomb } \\
\text { (2003) }\end{array}$ & $\begin{array}{l}\text { Overcoming the challenge of integrating } \\
\text { technical and market knowledge; build } \\
\text { capacity for technology-based } \\
\text { innovation }\end{array}$ \\
\hline \multirow[t]{3}{*}{$\begin{array}{l}\text { 4. Regional, } \\
\text { geographical, } \\
\text { community } \\
\text { development }\end{array}$} & Burress and Cook (2009) & $\begin{array}{l}\text { Local development; positive } \\
\text { externalities or agglomeration } \\
\text { economies; regional cooperation and } \\
\text { competitiveness }\end{array}$ \\
\hline & $\begin{array}{l}\text { Ndour and Alexandre- } \\
\text { Leclair (2015) }\end{array}$ & $\begin{array}{l}\text { Combining economic viability, } \\
\text { participatory governance, and social } \\
\text { innovation for women community } \\
\text { groups }\end{array}$ \\
\hline & Morgan (2016) & Building technology transfer \\
\hline
\end{tabular}




\begin{tabular}{|l|l|l|}
\hline \multirow{5}{*}{\begin{tabular}{|l|l|} 
5. Adoption of new \\
policies, regulations \\
and institutions
\end{tabular}} & Wijen and Ansari (2001) & $\begin{array}{l}\text { infrastructure that helps the regional } \\
\text { economy }\end{array}$ \\
\cline { 2 - 3 } & $\begin{array}{l}\text { Anderton and Setzer (2018) } \\
\text { Invention, diffusion and evaluation of } \\
\text { regional policies } \\
\text { policy; building capacity to sustain and } \\
\text { implement change }\end{array}$ \\
\cline { 2 - 3 } & Zito (2001) & $\begin{array}{l}\text { Setting agenda for policy, promoting a } \\
\text { political issue and potential solutions; } \\
\text { supporting and legitimizing new } \\
\text { policies }\end{array}$ \\
\cline { 2 - 3 } & $\begin{array}{l}\text { Meijerink and Huitema } \\
\text { (2010) }\end{array}$ & $\begin{array}{l}\text { Challenging the status quo and } \\
\text { influencing a change trajectory; helping } \\
\text { adoption of new policies }\end{array}$ \\
\cline { 2 - 3 } & $\begin{array}{l}\text { Corbett and Montgomery } \\
\text { (2017) }\end{array}$ & $\begin{array}{l}\text { Developing new regulations and } \\
\text { institutions; stimulation of large scale } \\
\text { transformations and changes }\end{array}$ \\
\cline { 2 - 3 } & $\begin{array}{l}\text { Handling social challenges, building } \\
\text { new institutions, and removing old } \\
\text { institutional arrangements }\end{array}$ \\
\hline
\end{tabular}

\subsection{Common Mechanisms of Collective Entrepreneurial Action}

Even though the prominence of collective entrepreneurship has been widely captured in the literature, research on how such entrepreneurial communities come into being, through what particular mechanisms they evolve is rather scarce. In collective entrepreneurship, certain mechanism should be established so that the collective action puzzle theorized by Olson (1965) could be resolved. That is, there is a need for a set of fundamental rules and processes to attain and sustain the collective and its entrepreneurial nature. Wijen and Ansari (2001) discuss these internal factors extensively. According to them, these key processes include i) effectively configuring the actors within the collective network so that power is concentrated; ii) creating a common ground through tactics encouraging cooperation among allies; iii) mobilizing actors around common objectives; iv) developing structural arrangements and appropriate incentive systems to boost cooperative behavior and reduce the costs associated with it; and finally, v) using the right mechanisms to implement the jointly agreed decisions and strategies.

A number of other studies have also discussed how collective entrepreneurial action successfully develops and sustained over time. Montgomery and his colleagues (2012) highlighted three key activities and strategies: In framing, innovative ideas are evaluated, perceived and socially interpreted. In turn, these shared meanings mobilize collective action and start change. During convening process, knowledge, skills, resources and expertise are recruited from different organizations which allows for effective collaboration. Innovation and 
co-creation can only be achieved by building communication, sharing and collective learning among participants (Montgomery et al., 2012). Finally, multivocality reflects that diverse perspectives and alternative ideas should be combined in order to connect with various audiences and to attain wider impacts. A similar conceptualization can be found in Riberio-Soriano and Urbano (2009)'s study where they identify negotiation, networking and decision-making as the three main processes in collaborative entrepreneurship.

Among different stages of collective entrepreneurship, theorizing and idea formation steps attract particular attention. Once experiences and perceptions activate the emergence of different ideas, the collective starts to imagine what opportunities and possible directions can be created (Felin and Zenger, 2009). Once initial entrepreneurial beliefs are developed like this, they are scrutinized, reasoned and justified towards more refined models or theories. Only after these theories are tested and proper feedback is received, real actions (e.g. forming a new product, a new organization, a new strategy) can be taken.

Aligning individual interests through collective understandings might especially be important in market creation. Towards this end, Corbett and Montgomery (2017) identified six main phases in market formation process. They include jointly recognizing problems and finding solutions; forming relationships and disseminating ideas; identifying and assembling necessary resources; reviewing, creating and modifying the organizational setup, and transferring the entrepreneurial idea into to field and legitimizing it.

\section{CORE ELEMENTS AND LEVELS OF COLLECTIVE ENTREPRENEURSHIP}

The above discussions imply how collective entrepreneurship may vary considerably with respect to its main drivers, types of participants, the way these participants interact, at what level it activates and what innovative solutions it can provide. Despite the existence of a number of common mechanisms, there is a significant diversity by which collective entrepreneurship is manifested in a given situation. Although there have been a few attempts for understanding this plurality (e.g., Davidsson and Wiklund, 2001; Burress and Cook, 2009; Montgomery et al., 2012), we still have very limited understanding about how entrepreneurship at a collective manner is shaped depending on what is targeted, who is involved, what defines the nature of collaboration and at what level(s) it is organized.

To this end, this study offers an inclusive framework to help make the analysis of collective entrepreneurship more understandable, refined and accurate. The proposed framework (see Figure 1) entails two major parts: a) level of entrepreneurship, b) elements of collective entrepreneurial efforts. Inspired by Davidsson and Wiklund's (2001) and Burress and Cook's (2009) studies, I identified four separate levels (all aggregate beyond an organization) at which 
collective entrepreneurship may emerge and its influences can be experienced. The lowest level constitutes inter-organizational relationships where collectivity is manifested by a tight network of organizations such as formal/informal strategic alliances and supple chain partnership where entrepreneurship is dispersed across customers, suppliers, distributors or other collaborators. At this level, the scope of entrepreneurship is often limited to joining forces to discovering and exploiting business opportunities for obtaining economic gains, increasing competitive advantage or developing a new product/service for the network members (see Category $1 \& 3$ in Table 1$)$.

At industry or cluster level, number of members in the collective increases (sometimes including all participants of an industry) and the relationships become less hierarchical. The emphasis shifts to broader expectations such as setting new industry standards, creating a new market category or legitimizing a new organization form (see Category 2 in Table 1). Resources are usually mobilized to construct new collective identities. At regional or community level, entrepreneurship is seen as a way to discover and use opportunities for regional economic growth and development or enhancing local innovation capacity (see Category $3 \& 4$ in Table 1). Accordingly, diverse local groups within a certain geography (e.g. businesses, community representatives, local governments) enter into collaboration. Typical examples include regional innovation systems and local climate initiatives. Finally, national/societal level represents the largest scope of collective entrepreneurship efforts with the aim of promoting broad-level social and political changes such as popularizing a political issue and potential solutions or initiating a new public policy (see Category 5 in Table 1). Although economic concerns are not dismissed, they are coupled with important social, cultural and political ones. To this end, even larger number of heterogeneous actors (e.g. government agencies, universities, social movements, business) interact towards mutual interests.

It should be added that there might also be an interplay among these levels so they should not be conceptualized as isolated from one another. Such interplay necessitates multi-level research designs and analysis (Davidsson and Wilkund, 2001). Typically, a development or change at an upper level could have significant effects for lower levels. For instance, a national level regulation or policy change would have important outcomes for regions, industries and markets. In other circumstances, the opposite can also be true where lower-level actions can be translated into more aggregate outcomes. Or, entrepreneurial efforts can be given simultaneously at different levels and at different fronts in a complementary way. Regardless of the starting point and the direction of influence, such dynamic interactions across levels should not be overlooked. 


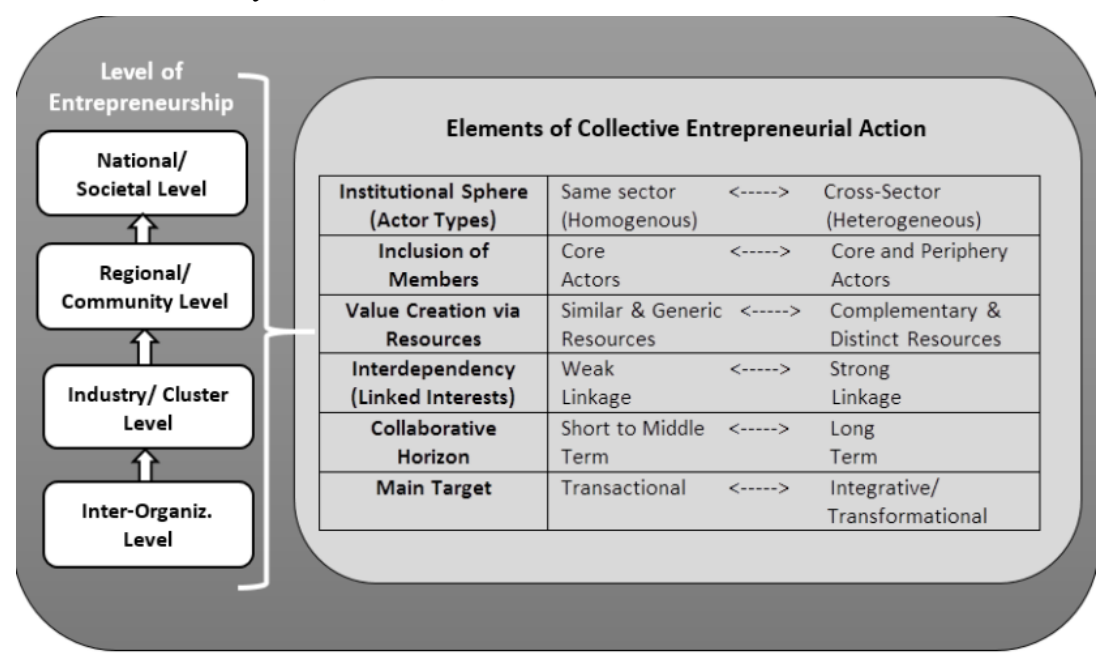

Figure 1. An Integrated Framework of Collective Entrepreneurship

The second part of the proposed framework comprise the key elements and decisions applicable to any collective entrepreneurship case. "Institutional sphere" reflects the composition of the collective with respect to its participants. Namely, if the partners come from the same single sector (.e.g. public, private, nongovernmental sectors) it becomes a more homogenous collective. In contrast, if actors from different sectors combine their forces, this makes it a more heterogeneous group. Actors within entrepreneurial collectives may also show plurality based on whether they actively participate in creating market opportunities by pooling valuable resources -as core actors-, or they solely assist these market making activities through support mechanisms -as periphery actors(Corbett and Montgomery, 2017).

An entrepreneurial initiative create value primarily through the recombination of resources. Yet this depends on the type and nature of resources to be recombined. Resources might be more similar and generic or more complementary and unique (Austin and Seitanidi, 2012; Montgomery et al., 2012). If they are more complementary and diverse, the extent of value creation is likely to increase as these resources are able to enhance collective capabilities and create alternative solutions. On the other hand, if they are very similar and generic, they will not add that much for attaining innovative outcomes.

Whether interests of individual actors in the entrepreneurial collective are closely linked or not is another essential dimension. When these interests are tightly linked, in other words, if interdependency between participants is high, it means their ideas, beliefs and actions are more in sync and they create value in a more synergistic way. Yet, members' goals and interests might be connected more 
loosely implying a weak linkage among them. Collective entrepreneurship may also differ depending on the time interval foreseen for the collaboration; it might be a short- or medium-term cooperation or a long-term initiative. Finally, main motivation for assembling the entrepreneurial capacity across multiple actors shapes the structure and direction of the collective endeavor. In some cases the goal is to initiate a radical change or transformation while in others the goal is limited to a set of transactions and the economic gain obtained through them.

It can be argued that the six elements identified in Figure 1 frequently manifest themselves in distinct combinations, that is, certain characteristics fit better than the others. For instance, if the entrepreneurial collective has a transformational goal, it often has a long-term horizon instead of a short-term one. Similarly, if actors that are collaborating come from diverse sectors, they typically bring distinct and complementary resources to the collective platform. Besides configurations among the six elements, proposed framework also reflects a further alignment: A meaningful match exists between identified characteristics and the level at which entrepreneurial action takes place. As one considers upper levels such as regional and societal domains, collective entrepreneurship turns out to be more heterogeneous involving both core and periphery actors across multiple sectors, carrying complementary sources rather than similar ones, planning for the long-term, and motivated to transform policies or institutions. On the other hand, the linkage of interests might be weaken as one climbs up through the identified levels of analysis.

\section{CONCLUSION}

This study represents an attempt for critically reviewing collective entrepreneurship research (e.g. major effects and common processes) and proposing an integrated framework for understanding in what ways such collaborative actions are established and vary. To do that, I suggested four different levels of entrepreneurship and six collective action characteristics by highlighting what they individually represent as well as how they interact.

This study contributes to the existing entrepreneurship research in multiple ways. First, it develops and offers a more realistic theoretical perspective of entrepreneurship above and beyond the idea of heroic individuals or single organizations as the essence of entrepreneurship (Weik, 2011). As such, it answers to the recent calls in the literature regarding the need for examining macro-level transformative power of entrepreneurial actions in organizational fields and the need for building more integrative (micro-macro) theoretical frameworks to understand entrepreneurship (Townsend, Hunt, McMullen and Sarasvathy, 2018). Second, it makes it clear what specific entrepreneurial conditions may lead to innovative outcomes as it outlines the key dimensions of collaborative action among business, government, non-governmental organizations and other actors as 
the basis of new policies, structures and fields (Etzkowitz and Klofsten, 2005). Third, this study identifies the possible ways in which single actors can recognize opportunities within the external economic, social, technological and institutional context depending on their position and connections in a field (Shepherd, Wennberg, Suddaby and Wiklund, 2019). Finally, it provides an opportunity to compare and contrast how the processes of individual vs. collective entrepreneurship differ from one another as well as their intersection points.

This study also brings a number of unique and useful insights to managers and practitioners. First, it helps them better evaluate how and when to engage in entrepreneurial activities in a collective manner so that they can generate innovative answers to collective problems. Indeed, the framework developed in this study can help them better assess the macro conditions and network possibilities which are likely to contribute to their innovation and future success. Moreover, it provides information to practitioners and entrepreneurs about how they can gain legitimacy for survival and what type of social context and relationships can produce it (Shepherd et al. 2019).

Nevertheless, the relationships suggested here should be further assessed and empirically tested. Future research can either adopt multiple comparative case designs or conduct statistical analysis on large quantitative data. New dimensions might also be included in the model where separate propositions are developed for each suggested interaction or influence. For instance, specific organizational attributes and resources such as financial and administrative resources, collective capability and innovation potential may shape the level of engagement in collaborative entrepreneurship (Franco and Haase, 2013).

The notion of "collective entrepreneurship" often corresponds with a number of similar conceptualizations in the literature. Hence, future studies should clarify how it is theoretically linked to other well-established concepts such as institutional entrepreneurship (Maguire et al. 2004; Micelotta et al. 2017), societal entrepreneurship (Montgomery et al. 2012), environmental entrepreneurship (Corbett and Montgomery, 2017; Doh et al. 2019) and policy entrepreneurship (Mintrom, 1997; Zito, 2001; Meijerink and Huitema, 2010). This will not only contribute to the discussion of what an entrepreneurial collective entails, but also support the refinement and advancement of these related literatures. Finally, researchers can investigate how the notion of collective entrepreneurship can be integrated to the recent discussions of sustainability, sustainable transformations and social entrepreneurship where multiple stakeholders and concerns are involved. 


\section{REFERENCES}

Anderton, K., \& Setzer, J. (2018). Subnational climate entrepreneurship:

Innovative climate action in California and São Paulo. Regional Environmental Change, 18(5), 1273-1284.

Anglin, A. H., McKenny, A. F., \& Short, J. C. (2018). The impact of collective

optimism on new venture creation and growth: A social contagion perspective. Entrepreneurship: Theory and Practice, 42(3), 390-425.

Auerswald, P. E., \& Branscomb, L. M. (2003). Start-ups and Spin-offs Collective

Entrepreneurship between Invention and Innovation. In: D. M. Hart (Ed.), The Emergence of Entrepreneurship Policy: Governance, Start-Ups, and Growth in the U.S. Knowledge Economy (pp. 61-91). Cambridge University Press.

Austin, J., \& Seitanidi, M. (2012). Collaborative value creation: A review of partnering between nonprofits and businesses: Part I. Value creation spectrum and collaboration stages. Nonprofit and Voluntary Sector Quarterly, 41(5), 726-758.

Bijman, J., \& Doorneweert, B. (2010). Collective entrepreneurship and the producer-owned cooperative. Journal of Cooperative Studies, 43(3), 5-16.

Burress, M., \& Cook, M. (2009). A primer on collective entrepreneurship: A preliminary taxonomy. Working Paper AEWP 2009-4, University of Missouri.

Cantù, C. (2018). Discovering the collective entrepreneurial opportunities through spatial relationships. IMP Journal, 12(2), 276-295.

Cooke, P. (2009). Regional innovation, collective entrepreneurship and green

clusters. In Smallbone, D., Landstrom, H., JonesEvans, D. (Eds.), Entrepreneurship and Growth in Local, Regional and National Economies: Frontiers in European Entrepreneurship (pp.17-48).

Corbett, J., \& Montgomery, A. W. (2017). Environmental entrepreneurship and interorganizational arrangements: A model of social-benefit market creation. Strategic Entrepreneurship Journal, 11(4), 422-440.

Davidsson, P., \& Wiklund, J. (2001). Levels of analysis in entrepreneurship re-

search: Current research practice and suggestions for the future. Entrepreneurship Theory \& Practice, 25(4), 81-100.

Doh, J. P., Tashman, P., \& Benischke, M. H. (2019). Adapting to grand

environmental challenges through collective entrepreneurship. Academy of Management Perspectives, 33(4), 450-468.

Dufays, F. (2013). Collective entrepreneurship, a solution to conflicting institutional logics in the entrepreneurship process? In P. Teirlinck, S.

Kelchtermans, F. DeBeule (Eds.), Proceedings of the 8th European

Conference on Innovation and Entrepreneurship, Vol.2 (pp. 715-722).

Hogeschool University Brussel, Belgium.

Emin, S., \& Guibert, G. (2017). Complexity and self-organization within collective entrepreneurship: An analysis of a local music scene. Revue Internationale P.M.E., 30(2), 87-113.

Etzkowitz, H., \& Klofsten, M. (2005). The innovating region: Toward a theory of knowledge-based regional development. $R \& D$ Management, 35: 243-255.

Felin, T., \& Zenger, T. (2009). Entrepreneurs as theorists: On the origins of 
collective beliefs and novel strategies. Strategic Entrepreneurship Journal, 3(2), 127-146. Franco, M., \& Haase, H. (2013). Firm resources and entrepreneurial orientation as determinants for collaborative entrepreneurship. Management Decision, 51(3), 680-696. Lee, B.H., Struben, J., \& Bingham, C. B. (2017). Collective action and market formation: An integrative framework. Strategic Management Journal, 39: 242- 266. Leyden, D. P. \& Lin, A. N. (2013). Knowledge spillovers, collective entrepreneurship, and economic growth: The role of universities. Small Business Economics, 41(4), 797-817.

Maguire, S., Hardy, C., \& Lawrence, T. B. (2004). Institutional entrepreneurship in emerging fields: HIV/AIDS treatment advocacy in Canada. Academy of Management Journal, 47(5), 657-679.

Malo, M. C., Buendia-Martinez, I., \& Vezina, M. (2012). A conceptualization of women's collective entrepreneurship: From strategic perspectives to public Ppolicies. In Galindo, M. A., Riberio, D. (Eds.), Women's Entrepreneurship and Economics: New Perspectives, Practices and Policies (pp.211-224).

Meijerink, S. and Huitema, D. (2010). Policy Entrepreneurs and Change Strategies: Lessons from Sixteen Cases. Ecology and Society, 15(2), 21-40. Meyer, C. (2020). The commons: A model for understanding collective action and entrepreneurship in communities. Journal of Business Venturing, 35(5).106-134. Micelotta, E., Lounsbury, M., \& Greenwood, R. (2017). Pathways of Institutional Change: An Integrative Review and Research Agenda. Journal of Management, 43(6), 1885-1910.

Miles, R. E., Miles, G., \& Snow, C. C. (2006). Collaborative entrepreneurship: A business model for continuous innovation. Organization Dynamics, 35(1), $1-11$. Mintrom, M. (1997). Policy entrepreneurs and the diffusion of innovation. American Journal of Political Science, 41(3), 738-770.

Montgomery, A. W., Dacin, P. A., \& Dacin, M. T. (2012). Collective social entrepreneurship: Collaboratively shaping social good. Journal of Business Ethics, 111(3), $375-388$.

Morgan, K. (2016). Collective entrepreneurship: The Basque model of innovation.

European Planning Studies, 24(8), 1544-1560.

Ndour, M., \& Alexandre-Leclair, L. (2015). Community groups and female entrepreneurship in developing countries: A study of a Senegalese case. Proceedings of the European Conference on Innovation and Entrepreneurship, pp. 485-493.

Lounsbury, M. (1998). Collective entrepreneurship: The mobilization of college and university recycling coordinators. Journal of Organizational Change Management, 11(1), 50-69.

Olson, M. (1965). The Logic of Collective Action: Public Goods and the Theory of Groups, Cambridge, MA: Harvard University Press.

Pathak, S. (2019). Recommendations for under-represented entrepreneurship.

Journal of Enterprising Communities, 13(1-2), 167-177.

Rao, H., Morrill, C., \& Zald, M. N. (2000). Power plays: How social movements 
and collective action create new organizational forms. Research in Organizational Behavior, 22, 237-281.

Ribeiro-Soriano, D., \& Urbano, D. (2009). Overview of collaborative

entrepreneurship: An integrated approach between business decisions and negotiations. Group Decision and Negotiation, 18(5), 419-430.

Sarpong, D., AbdRazak, A., Alexander, E., \& Meissner, D. (2017). Organizing

practices of university, industry and government that facilitate (or impede) the transition to a hybrid triple helix model of innovation. Technological Forecasting and Social Change, 123, 142-152.

Schoonhoven, C. B., \& Romanelli, E. (Eds.). (2001). The Entrepreneurship

dynamic: Origins of entrepreneurship and the evolution of industries, Stanford, CA: Stanford University Press.

Shepherd, D.A., Wennberg, K, Suddaby, R., \& Wiklund, J. (2019). What are we

explaining? A review and agenda on initiating, engaging, performing, and contextualizing entrepreneurship. Journal of Management, 45(1), 159-196.

Silva, M, R., \& Rodrigues, H. (2005). Public-private partnerships and the

promotion of collective entrepreneurship. FEP Working Papers, University of Porto, pp. 127.

Townsend, D. M., Hunt, R. A., McMullen, J. S., \& Sarasvathy, S. D. (2018).

Uncertainty, knowledge problems, and entrepreneurial action. The Academy of Management Annals, 12(2), 659-687.

Weick, E. (2011). Institutional Entrepreneurship and Agency. Journal for the

Theory of Social Behavior, 41(4), 466-481.

Wigger, K., A., \& Shepherd, D. A. (2020). We're all in the same boat: A collective

model of preserving and accessing nature-based opportunities. Entrepreneurship Theory and Practice, 44(3), 587-617.

Wijen, F., \& Ansari, S. (2007). Overcoming inaction through collective

institutional entrepreneurship: Insights from regime theory. Organization Studies, 28(7), 1079-1100.

Yan, J., \& Yan, L. (2017). Collective entrepreneurship, environmental uncertainty

and small business performance: A contingent examination. The Journal of Entrepreneurship, 26(1). 1-26.

Zito, A. R. (2001). Epistemic communities, collective entrepreneurship and

European integration. Journal of European Public Policy, 8(4), 585-603. 